\title{
12th Annual Sask. Christmas Bird Count
}

We hope that many of our Saskatchewan members will be able to take part in our twelfth annual Christmas bird count. Make your observations while going about your daily work, but try to go for a hike for an hour or two. We would like everyone to spend at least four hours afield, and preferably seven (the latter is necessary to meet Audubon Society requirements). Certainly we will disqualify all reports covering less than two hours, or failing to follow directions. All the observers in one locality should make their counts the same day and submit only one report. The area covered should be no more than 20 miles in diameter if roads are open in several directions. Please send your reports promptly the first week in January.

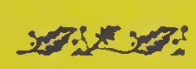

\section{APPRECIATION}

October 2, 1953

Following are quotations from a letter received by Dr. Stuart Houston and written by Mrs. Herbert E. Carnes (Betty Carnes), President Emeritus of the New Jersey Audubon Society and Chairman of the American Ornithologist's Union:

"I wish I could adequately express my very great delight in receiving from you those copies of the "Blue Jay". I read them through from cover to cover with the very special sort of interest given by one who once aspired to do something similar and failed. The pleasant homey touch which I once tried to inject in our N.J. state publication is so much a part and parcel of the "Blue Jay" that, as I read it, I kept saying to myself, "If only I had more of these, so that others here might see what we might one day aspire to'.

Once upon a time it was my dream to first establish a permanent home and headquarters for our state Audubon Society and then launch a publication similar to the "Blue Jay." I did manage to establish their own home for them, but our publication is still that dry as dust affair with dull records of birds seen months ago, notices of field trips for the future, but practically really nothing informative on birds and other wildlife. There are many publications for the expert observers but far too few aimed at beginner and expert alike. If groups, like ours, are to grow and thrive, there must be articles definitely planned to capture the interest of the casual (at first) bird observer. The "Blue Jay" is exceedingly well rounded and I want more of them to send to others whom I am trying to interest in getting out such a publication down here. So here is my check for $\$ 5.00$ to insure my receiving copies of your magazine for the next five years. I shall use your gift copies to wave under the noses of the uninspired, to show them what can be done, once intelligent direction takes over. Certainly yours is the best dollar value I could possibly imagine. I wish it could be done here." 